\title{
COPPER AND CERULOPLASMIN CONCENTRATIONS IN THE BLOOD SERUM OF SCHIZOPHRENIC PATIENTS
}

\author{
Luís MARques-Assis * \\ Francisco Bastos De Jorge **
}

In spite of the large number of studies made up to now the exact biological meaning of copper is not known.

The investigations about this element in neuropsychiatric pathology have been concerned mostly with hepatolenticular degeneration, multiple sclerosis, epilepsy and schizophrenia. In our previous publications attention was focused on copper metabolism alterations in epilepsy ${ }^{3,}$. . The aim of the present work is to study the behaviour of total copper and ceruloplasmin in the serum of schizophrenic patients, due do the lack of agreement of the available data on the literature.

\section{MATERIAL AND METHODS}

Of a total of 45 patients, 39 came from a private clinic and 6 from the Psychiatric Clinic of the Medical School of the University of São Paulo. Forthy-three patients were male and two were females, the age varying from 17 to 42 years. The sample included 38 white, 6 mulatoes and one japonese descendent patients.

In 36 cases, blood samples were secured for total copper determination in the serum; in 20 cases, determination of ceruloplasmin were also made. The biood was collected from patients that had been for at least three hours in a fasting condition. Completely clean and dry tubes, syringes and needles were used. The samples were centrifuged 3 to 4 hour after collection, determinations being made on the same day, or the serum, after centrifugation, was stored at $-10^{\circ} \mathrm{C}$.

The method used for the copper determinations was the one based on the reaction of sodium diethyldithiocarbamate with the cupric ion, in an ammoniacal medium containing citrate and pyrophosphate; the color of the resulting copper diethildithiocarbamate was stabilized with polyvinyl alcohol of grade 52-22\%. Cerulcplasmin activity was determined by the Houchin method"t, after correction for the normal color of the blood serum.

As shown in previous publications ${ }^{7,8}$ normal values are $108 \mu \mathrm{g} / 100 \mathrm{ml}$ for copper and $33.4 \mathrm{mg} / 100 \mathrm{ml}$ for ceruloplasmin.

The results presented here were subjected to conventional statistical analysis.

From the Departments of Neurology (Prof. A. Tolosa) and Medicine (Prof. A. B. Ulhoa Cintra), University of São Paulo Medicinal School: " Assistant Professor; $\because *$ Chier. Laboratory. 


\section{RESULTS}

Table 1 summarizes the results obtained showing that the slight increase of copper in schizophrenic patients is statistically significant. No significant variations in the ceruloplasmin levels were detected.

\begin{tabular}{|c|c|c|c|c|c|c|c|}
\hline & & Mean & $\pm s . d$. & $M x$ & $M n$ & $t$ & D.f. \\
\hline \multirow[b]{2}{*}{ Copper } & $\begin{array}{l}\text { normals } \\
\quad \text { (20 cases) }\end{array}$ & 108.1 & 9.7 & 125 & 90 & \multirow[b]{2}{*}{$3.893 *$} & \multirow[b]{2}{*}{44} \\
\hline & $\begin{array}{l}\text { schizophrenics } \\
\text { ( } 26 \text { cases) }\end{array}$ & 13.1 & 25.9 & 190 & 96 & & \\
\hline \multirow{2}{*}{$\begin{array}{l}\text { Cerulo- } \\
\text { plasmin }\end{array}$} & $\begin{array}{l}\text { normals } \\
\text { (17 cases })\end{array}$ & 29.94 & 3.78 & 34.9 & 22.5 & \multirow{2}{*}{0.229} & \multirow{2}{*}{35} \\
\hline & $\begin{array}{l}\text { schizophrenics } \\
\text { (20 cases) }\end{array}$ & 31.7 & 8.99 & 50.3 & 21.5 & & \\
\hline
\end{tabular}

Table 1 - Copper ( $1 / 100 \mathrm{ml})$ and ceruloplasmin $(\mathrm{mg} / 100 \mathrm{ml})$ concentrations in the blood serum of schizophrenic patients. * Significant value $(P<0.001)$.

\section{DISCUSSION}

The available conclusions from previous work are not meaningful on what relates to copper and ceruloplasmin in schizophrenia. Plum and Hansen's ${ }^{20}$ revision call attention to the lack of agreement of previous observations, since while some authors found normal levels of copper and/or ceruloplasmin in the blood serum of schizophrenic patients $4,10,12,15,1 \overline{1}, 18$, others found increased values $1,2,5,11,13,19,20,21$. Leach et al. 16 and Abood et al. 1 admit the action of ceruloplasmin on the metabolism of adrenaline, serotonine and histamine and they attach a high value on the seric levels of this enzyme for the understanding of metabolic disorders in schizophrenia. This hypotesis is not confirmed by the data obtained in the present investigation, since the level of ceruloplasmin does not show significant deviations in the patients under study.

It is possible that the direct reacting copper may be responsible by the increase of total copper in the blood serum, but the authors would like to point out that the slightly amounts of copper in schizophrenic patients may have not a diagnostic value.

\section{SUMMARY AND CONCLUSIONS}

The serum copper (26 cases) and ceruloplasmin (20 cases) are studied in 45 patients with schizophrenia. The following conclusions were drawn from this study: 1) the blood copper is significantly higher in patients 
with schizophrenia; 2) the variations of ceruloplasmin are not significant. The slightly amounts of copper in schizophrenia may have not a diagnostic value.

\section{RESUMO E CONLUSOES}

Concentrações do cobre e da ceruloplasmina no plasma de pacientes com esquizofrenia

É estudado o comportamento do cobre total do sôro (26 casos) e da ceruloplasmina ( 20 casos) em 45 pacientes portadores de esquizofrenia. A análise estatística dos resultados permitiu aos autores chegarem às seguintes conclusōes: 1) o cobre total do sôro está aumentado nos pacientes esquizofrênicos; 2) os níveis de ceruloplasmina não variaram de maneira significativa. Os autores julgam que os achados podem não ter valor diagnóstico.

\section{REFERENCES}

1. ABOOD, L. G.; GIBBS, F. A. \& GIBBS, E. - Comparative study blood ceruloplasmin in schizophrenia and other disorders. Arch. Neurol. Psychiat. (Chicago) $77: 643-645,1957$.

2. ANGEL, C.; LEACH, B. E.; MARTENS, S. OHEN, M. \& HEATH, R. G. Serum oxidation tests in schizophrenic and normal subjects. Arch. Neurol. Psychiat. (Chicago) 78:500-504, 1957.

3. ASSIS, L. M. - Metabolismo do cobre nas epilepsias. Arq. Neuro-Psiquiat. (São Paulo) 24:229-246, 1966.

4. BAKWIN, R. M.; MOSBACH, E. H. \& BAKWIN, H. - Concentration of copper in serum of children with schizophrenia. Pediatrics 27:642-644, 1961.

5. BOVI, A. \& MASCELlANI, A. - Determinazione del tasso di rame serico negli schizoprenici. G. Psichiat. Neuropat. 86:163-173, 1958.

6. CANELAS, H. M.;ASSIS, L. M.; DE JORGE, F. B.; TOLOSA, A. P. M. \& CINTRA, A. B. U. - Disorders of copper metabolism in epilepsy. Acta neurol. scand. $40: 97-106,1964$.

7. DE JORGE, F. B.; CANELAS, H. M. \& SPINA-FRANCA, A. - Contribuição ao estudo do metabolismo do cobre. Valôres normais no sôro sangüineo, líquido cefalorraqueano e urina. Rev. paul. Med. 62:125-128, 1963.

8. DE JORGE, F. B. \& CANELAS, H. M. - Contribuição ao estudo da ceruloplasmina. Valôres normais no sôro sangüineo. Arq. Neuro-Psiquiat. (São Paulo) 22:271-276, 1964.

9. DE JORGE, F. B.; CANELAS, H. M. \& COSTA-SILVA, A. - Contribuição ao estudo do metabolismo do cobre. Metodologia da determinação do cobre em materiais biológicos. Rev. paul. Med. 61:350-355, 1962.

10. EDELSTEIN, E. L. \& KRASSILOWSKY, D. - A study on serum copper level in 20 acute schizophrenics. J. ment. Sci. 105:511-51.3, 1959. 
11. ESCOBAR, A. I. \& NIETTO, D. - The role of copper in metal disorders. Bol. Inst. Estud. méd. biol. Mexico, 15:159-170, 1957.

12. FROHMAN, C. E.; GOODMAN, M.; LUBY, E. D.; BECKETT, P. G. S. \& SENF, R. - Ceruloplasmin, transferrin and tryptophan in schizophrenia. Arch. Neurol. Psychiat. (Chicago) 79:730-734, 1958.

13. HELMEYER, L.; KEIDERLING, W. \& STUWE, G. - Kupfer und Eisen als korpereigene Wirkstoffe und ihre Bedeutung bein Krankheitsgeschehen. $G$. Fischer, Yena, 1941.

14. HOUCHIN, D. B. - A rapid colorimetric method for the quantitative determination of copper oxidase activity (ceruloplasmin). Clin. Chem. 4:519-523, 1958.

15. KOLAKOWSKA, T,; SZAJBEL, W. \& MURAWSKI, K. - Ceruloplasmina i miedz W surowic $\mathrm{W}$ schizofrenii. Psychiat. Polska 10:691-696, 1960.

16. LEACH, B. E.; COHEN, M.; HEAT, R. \& MARTENS, S. - Studies of the role of ceruloplasmin and albumin in adrenaline metabolism. Arch. Neurol. Psychiat. (Chicago) 76:635-642, 1956.

17. MUNCH-PETERSEN, S. - On serum copper in patients with schizophrenia. Acta psychiat. scand. 25:423-427, 1950.

18. O'REILLY, S. - Observations on ceruloplasmin and methods for its esti.* mation. Neurology (Minneapolis) 11:259-265, 1961.

19. OSANAI, Y. - Clinical studies on serum copper metabolism in patients with mental and nervous diseases. Tohoku med. J. 65:1-22, 1962.

20. PLUM, C. M. \& HANSEN, S. E. - Studies on variation in serum copper and serum copper oxidase activity, together with studies on the copper content of the cerebrospinal fluid, with particular reference to the variations in multiple sclerosis. Acta psychiat. scand. Supl. 148, 1960.

21. SCHEINBERG, H. \& MORELL, A. G. - Concentration of ceruloplasmin in plasma of schizophrenic patients. Science 126:925-926, 1957.

Clinica Neurológica - Faculdade de Medicina da Universidade de São Paulo Caixa Postal 3461 - São Paulo, SP, Brasil. 